\title{
Degraded Grades - Do Graduate Grades Provide a Useful Guide to Potential ICT Employers?
}

\author{
Tony Richardson \\ Massey University at Albany, Auckland, New Zealand
}

\section{t.s.richardson@massey.ac.nz}

\begin{abstract}
Over the past decade, the New Zealand government has instituted radical changes to the tertiary sector financial infrastructure. As their traditional benchmarks of student ability and aptitude have been eroded, the consequences for employers and their recruiting practices have been largely ignored. This paper examines the reasons for this erosion and points to factors that have influenced the decline, particularly in the notion that grades are a real indicator of aptitude.
\end{abstract}

Keywords: Assessment, ICT Employers, Tertiary Funding, Research Pressure, University Teaching

\section{Introduction}

This paper serves as an introduction to a wide-ranging and ongoing research project. As such, it aims to identify a major flaw in the current grading practices of academic institutions and questions whether the identified diverging goals of academia and the Information and Communications Technology (ICT) industry present an opportunity for major changes in student assessment. The research that has led to the views expressed here indicate that a crisis of confidence exists within graduate ICT employers and that if Universities do not fill the void other, non-academic certifiers will.

The ICT industry evolves around change. Typically, very rapid change, in the technologies themselves and in the methodologies used to add value to those technologies. The demands of the industry call for employees who embrace rapid change, who are able to communicate ideas and practices and who can demonstrate their decision-making skills while working within a typical team environment. Surprisingly, given this dynamic nature, preferred graduate profiles as specified by ICT employers appear to have remained remarkably constant over recent decades. Lucia Baillie typifies employers" requirements when she reports them as "basic programming skills, communication, problem-solving and teamwork" (Baillie, 1999). Another observable constant is that ICT employers perceive their largest pool of untapped potential employees to be the Universities and their recruitment filtration method has traditionally been the grades with which students graduate. While glacial in comparison with ICT, the Universities have also changed. So much so, that it is questionable whether grades continue to be a useful and reliable indicator to ICT em-

Material published as part of this journal, either on-line or in print, is copyrighted by Informing Science. Permission to make digital or paper copy of part or all of these works for personal or classroom use is granted without fee provided that the copies are not made or distributed for profit or commercial advantage AND that copies 1) bear this notice in full and 2) give the full citation on the first page. It is permissible to abstract these works so long as credit is given. To copy in all other cases or to republish or to post on a server or to redistribute to lists requires specific permission from the publisher at Publisher@InformingScience.org ployers of the qualities of their prospective graduate employees. This paper seeks to examine the apparent divergence between the objectives of Government, Universities and the potential employers of ICT graduates within New Zealand. 


\section{Change and Divergence}

\section{The Changing Nature of Universities}

New Zealand is a young country. When Englishman Captain James Cook first visited New Zealand in the eighteenth century, the concept of the modern University was already well established in his homeland and across much of Europe. Essentially a preserve of the wealthy elite, the Universities of the day provided a final formal education for the, predominantly, sons of the ruling classes; an environment of learning and scholarship, which was considered enlightening and nonvocational. This academic idyll has proven to be an enduring and powerful image of the University, so much so that in the minds of many academics little has conceptually changed. There is a strong desire among some faculty for Universities to be divorced from industrial reality. To be more influenced by higher ideals of learning and culture than trade, commerce and the economic needs of a nation and its workforce. To remain a place where the world and its works are studied, discussed and contemplated upon, but not actually interacted with and where the influence of outsiders is to be resisted. In Europe this nostalgically desirable world was, until relatively recently, maintained largely through endowments. In New Zealand this has not been the case. The taxpayer has in fact funded New Zealand tertiary education since its inception. The New Zealand government controls the Universities' funding structure and it is the funding structure that has changed of late. It is this financial shift, which has changed the very nature and outlook of this particular economic sector.

Ivana Milojevic proposes six possible models for a $21^{\text {st }}$ century University (Milojevic, 1998). In New Zealand, what has evolved is a tertiary sector composed of a small number of what she would describe as "corporate Universities". The commercialisation of the tertiary education sector has seen the introduction of private enterprise providers and a reduction in per capita state funding for students. Additionally, an increase in financial monitoring has been accompanied by a shift to user-pays philosophy, resulting in increased fees and high levels of student debt. Critics of this approach see few if any positive spin-offs for Universities, faculty or students, academics now being subjected to market discipline by proxy, their students transformed into consumers and degrees becoming products (Fitzsimons, 2004).

The New Zealand government on the other hand sees the changes as positive "reforms", as a repositioning of tertiary education providers so as to better deliver its social and economic goals.

"Tertiary providers are moving to ensure that their programmes are relevant to the needs of employers and the wider community... The tertiary education reforms have brought the tertiary system closer to communities and businesses and aligned tertiary education closer to the governments social, economic and environmental goals. There was a need to increase New Zealanders sense of connection with the tertiary education system, to make it more responsive and accountable to those who look to it to shape the skills and knowledge that will increase their future well being." (STEP, 2004).

A desire on behalf of the New Zealand government to enhance what is described as capability and quality (STEP, 2004) has manifested itself as further funding restrictions, linking quantity and quality of faculty research output with a percentage of overall University funding. This shift in attitude of the financial stakeholder has bought about a systemic change to both faculty and students and as an unforeseen consequence to the very nature of student assessment.

\section{The Changing Nature of the Marketplace}

However, there is another factor that feeds into this equation. Until a policy change by government in 1999 there were only 675 full fee-paying students (FFPS) in New Zealand, i.e. interna- 
tional students who intended to return to their home countries on completion of their education. By 2002 this number had jumped to 80,000. China in particular values a New Zealand tertiary qualification and today Chinese students dominate undergraduate classes and form $39.6 \%$ of all international students (Berno \& Ward, 2003). In the changed financial climate outlined above, Universities are well aware of the significant influence that this market bears. It would be wrong to suggest that courses are being designed specifically for the international market, but there is a danger that New Zealand University courses will continue to reflect overseas graduate profiles just as they are diverging from those of the domestic New Zealand ICT industry. Why should this divergence happen?

In the early 1990s, Ed Yourdon prophesied that the American programmer was about to share the same fate as that of the Dodo (Yourdon, 1993). Yourdon's reasoning was that nations that possessed a significant competitive advantage for ICT development would trigger an outsourcing flow of traditional jobs from the USA to, particularly, India. The extreme pessimism of Yourdon's book has not come to pass, largely due to the considerable growth of the US market in the 1990s coupled with the emergence of the Internet. However, this disguises the fact that much outsourcing has indeed taken place, particularly, as predicted, from the USA to India. Much of the legacy maintenance and evolution work has transferred to the low labour cost environment of Bangalore and other Indian centres.

While short term, New Zealand could potentially benefit from similar outsourcing flows, long term it is set to suffer the same fate as predicted by Yourdon for the USA, only much faster and to a different country. The headlong growth of the Chinese economy poses a far greater threat to New Zealand ICT companies than India. China is part of the New Zealand sphere, China is seen as a huge potential market for New Zealand primary produce and there is a growing population of Chinese New Zealanders and New Zealand educated Chinese. The commoditisation if ICT as referred to by Carr (Carr, 2004), provides a further spur to the outsourcing of traditional jobs. Lowest cost operations become paramount when there is no apparent strategic or competitive advantage to burgeoning corporate ICT budgets.

Accordingly, a case could be made for the domestic New Zealand ICT marketplace to shift from traditional ICT work to more niche and specialised areas of systems development; markets such as mobile and wireless systems, entertainment, multimedia, virtual reality and so on displacing the established sectors of transaction processing, sales processing and stock control. In this scenario, the desire that New Zealand Universities and ICT employers "work together to ensure a close fit between the skills and knowledge that tertiary providers produce and those that are relevant to the economy, now and in the future" (STEP, 2004) highlight an economic conflict of interest. If the majority of New Zealand ICT students have a graduate profile that differs significantly from that of the New Zealand domestic ICT market, how will New Zealand employers value a New Zealand University degree? Further, how has this shift in the University market affected assessment processes and the consequent grades with which students emerge?

\section{The Changing Nature of Assessment}

In the idyllic times referred to earlier, student assessment was carried out utilising a series of oneon-one oral interviews. A bachelor was mentored and then assessed by a master after reading a set of prescribed texts. There were no standardised tests and there were far fewer students. The British Foreign Office was first to introduce entrance examinations as a means of ensuring quality amongst its intake and the notion of grades as a measure of potential aptitude has flowed on from there.

When degree qualifications become commodities they are subject to the vagaries of the marketplace and, more specifically, of marketing. New Zealand Universities have seen a burgeoning of 
different degree qualifications in recent years. In my own University, Information Systems can be undertaken within 5 different degrees, the Bachelor of Science (BSc), the Bachelor of Information Science (BinfSc), the Bachelor of Business Studies (BBS), the Bachelor of Arts (BA) and the Bachelor of Business Information Systems (BBIS). Additionally, within the BBS there are three different Information Systems majors, the e-business major, the Information Systems Development major and the plain vanilla Information Systems major; all of this on one campus of a multicampus University, each campus having its own variation on the same theme. The argument in favour of this arrangement is driven by the University's marketing division, broadening the appeal of the product and attracting more consumers, but leads to inevitable confusion when a potential employer is faced with the task of deconstructing the student's academic transcript.

While employers seek simplicity, clarity and standardisation in tertiary qualifications there is little sign that the Universities, running counter to their corporate marketing strategies, will generate momentum for such an initiative. Meanwhile, the New Zealand Government, acknowledging the plethora of related qualifications, is calling for "...a 'shared language' about competencies for educators, learners and employers" (STEP, 2004). Potential employers then, while unclear about the content of students' degree programmes must attempt to assess the relative quality of their candidate employees.

There is continuing high quality research being done on the nature, effectiveness and validity of teaching and assessment in tertiary institutions (Crooks, 2004; Drennan, 2001; Maki, 2004; Stobart \& Gipps, 1997). However, regardless of the actual rigor, or lack of, in assessment practice, New Zealand ICT companies examine student grades as a means to filter applicants, many expressing pride at the fact that they "only accept 'A' grade students". But is this view actually valid? The macro changes outline earlier have had unforeseen consequences at the micro level of student grading. These changes appear not to have resulted from any planned or managed policy shift, but from a pragmatic response on behalf of academic faculty to accommodate the ramifications of changing circumstances.

\section{Lifetime of learning}

In a laudable move and in response to the dynamic employment market, the government has instituted a drive to deliver "skills for work and life" (STEP, 2004). To facilitate multiple changes of career and lifelong education among the New Zealand population, the Universities have had their doors opened wider. The spectrum of abilities among the students in any one particular undergraduate class is now much larger than at any time in the recent past. This puts additional pressure on faculty in course management, teaching, tutorial and assessment. Though the aims of the policy are noble, the effect has been a downward slip in the average academic quality of a typical undergraduate class.

\section{High percentage of international students}

The rapid and phenomenal growth in the numbers of international students referred to earlier, coupled with a high number of non-English speaking recent immigrants eager for a New Zealand tertiary qualification, has further diluted the abilities of the student body in basic English communication skills. The pragmatic response of faculty has been to increase the number of multiplechoice type examinations and a shift towards summative assessments. In ICT courses there is now almost no written work submitted by students for assessment under examination conditions.

\section{Pressure to pass}

Norm-referenced grading is applied to many ICT courses. That is, students amass a total mark for their course, which ranks them in comparison to their classmates; the cut-off points between grades are then adjusted to give a normal distribution (bell curve) of grades. The result of this is 
to give a consistent percentage of "A"s, "B"s, "C"s, passes and fails year on year. Given government's stated priority: "A competencies-based approach describes a learner's ability to adapt to changing skills requirements and, therefore their ability to meet the challenges of a knowledge society" (STEP, 2004), this policy appears to be at odds with the wishes of a major stakeholder. Additionally, from the potential employer's point of view, when a student is graded relative to classmates of a particular cohort rather than a set of desired outcomes and competencies, the utility of the grade is significantly eroded.

\section{Pressure for more research}

As outlined earlier, in its strive to develop "stronger, more focussed research programmes" (STEP, 2004), the New Zealand government has instituted a policy of research-based funding for tertiary institutions. This policy has promoted a de-emphasising of teaching and a premium on research output, the consequence of which has seen junior faculty placed at the front of the class and a general edict to teach less. When coupled with pressure to pass the inevitable result appears to be a further erosion of the validity of student grades. When linking with academic promotion raises the pressure for more research, so inevitably will the quality of teaching decline. Drennan's study into a similar approach in the UK found that as long as UK funding councils favour large institutional awards for excellence in research and much smaller rewards for excellence in teaching, individual academics will choose to concentrate their activities in research activity, to the detriment of teaching (Drennan, 2004).

\section{The employer's last hope}

Given all the above, the potential employer of a contemporary ICT graduate is faced with a daunting task. The cost of recruitment is significant. The legislative machinations and the consequent costs of counselling-out the wrong employee are even greater. The structure and content of any particular student's degree is unclear, the equivalence of qualifications is vague and the final grades of any single student are an unreliable indicator of abilities when compared to a set of desired competencies. Can the hapless employer take heart from the simple observation of social behaviour that the type of person required will inevitably attend University? Can the employer conclude that any rational person will wish to upskill in order to gain a higher reward and therefore, to equate academic qualifications with upskilling is reasonable?

Even this last bastion of employer rationality is questionable. Dillingham concluded that more university-degreed workers don't necessarily mean that there are more highly skilled workers. It depends upon the actual degree and job (Dillingham, 2002). The belief that the most ambitious, able and brightest of society enter university as a matter of course due to significantly higher income earning potential, is possibly dubious. In his study on qualifications, upskilling and rewards, Dillingham remarks that "In the age of the purported high-skill boom, the real return to those with the highest qualifications stayed about the same between 1991 and 2001." (Dillingham, 2002).

Given the relatively small differential between tertiary qualified and high school qualified ICT employees in New Zealand and the consequently high opportunity cost of completing a degree, compounded by a significant burden of student loan debt, one could argue that the brightest of potential ICT employees would class a degree as not economically viable.

\section{Conclusion}

The divergence of goals between University stakeholders has created a ripple down effect, which threatens the validity of university programmes, the relevance of student grades and the long-term viability of tertiary ICT education. While employers demand certainty, stability and simplicity, 
Universities are pressured to deliver ambiguity, complexity and variation. A consequence of this has been the increasing value placed by employers on commercial certification by manufacturers such as Microsoft and Cisco, a disillusionment with University ICT education and allegations that they produce "A" grade graduates who can't write an English sentence. An ongoing research project, following on from this introductory paper, is intended to develop and implement a simulation system and test its validity against ICT employers' requirements. The research project will attempt to answer the question "is candidate specification via analogy, rather than by academic grades, a more appropriate model for ICT graduate recruitment?"

\section{References}

Baillie, L., (2000). IT employers' skills demands: Do they know what they want? Retrieved 29/11/04 from http://www.soi.city.ac.uk/liaison/Conference\%20Papers/HertsPaper.pdf

Berno, T., \& Ward, C. (2003). Cross-cultural and educational adaptation of Asian students in New Zealand. Retrieved 30/11/04 from http://www.asia2000.org.nz/about/programmes/research/various/Ward\%20and\%20Berno\%20report.pd $\underline{\mathrm{f}}$

Carr, N. (2004). Does IT matter? Harvard Business School Press.

Crawford, K., \& Fekete, A. (1997). What do exam results really measure? Proceedings of the 2nd Australasian Conference on Computer Science Education. Melbourne.

Crooks, T. (2004). Tensions between assessment for learning and assessment for qualifications: Presented at the $3^{\text {rd }}$ Conference of Commonwealth Examinations and Accreditation Bodies (ACEAB), Nadi.

Daniels, M., Berglund, A., \& Pears, A. (2004). Five myths of assessment: Proceedings of the $6^{\text {th }}$ Australasian Conference on Computing Education (ACE2004). Dunedin.

Dillingham, S. (2002). New Zealand workforce: Qualifications and evidence of upskilling. Retrieved from http://www.dol.govt.nz/PDFs/new-zealand-labour-upskilling.pdf

Drennan, L. (2001). Quality assessment and the tension between teaching and research. Quality in Higher Education, 7 (3), 167-178.

Fitzsimons, M. (2004). Managerialism and the university: New Zealand Journal of Tertiary Education Policy, 1 (1), 16-18.

Kerr, R. (2001). Education and economic growth. [Speech to Stokes Valley Rotary Club representing New Zealand Business Round Table.]

Maki, P. (2004). Assessing for learning: Building a sustainable commitment across the institution (pp. 85118). Sterling VA: Stylus Publishing.

Milojevic, I. (1998). Women's higher education in the $21^{\text {st }}$ Century: Futures Journal, 30 (7), 693-703.

New Zealand Department of Labour: Occupational Trends in New Zealand: 1991-2001. Retrieved from http://www.dol.govt.nz/publication-view.asp?ID=169

STEP - New Zealand Ministry of Education, Statement of Tertiary Education Priorities 2005 - 2007 Discussion Document. (2004). Retrieved from http://www.minedu.govt.nz/web/downloadable/d19986_v1/9986-download-step2004.pdf

Stobart, S., \& Gipps, C. (1997). Assessment - A teacher's guide to the issues. Hodder and Stoughton.

Yourdon, E. (1993). The decline and fall of the American programmer. Englewood Cliffs, NJ: Prentice Hall. 


\section{Biography}

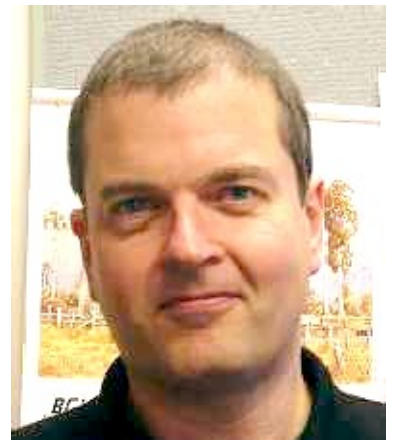

Tony Richardson is a Senior Lecturer in Information Systems at Massey University, Auckland, New Zealand. His experience in the field spans 25 years, both as a practitioner and academic. Tony has extensive business ICT expertise and consults regularly with New Zealand based corporates.

Tony has interests in systems development, database, networks and, latterly, graphics. He is currently researching a $\mathrm{PhD}$ centred on computer based assessment via simulation. 